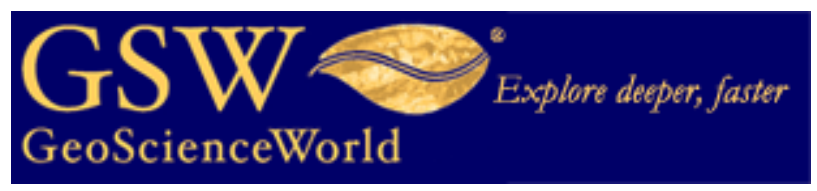

GSW Home GeoRef Home My GSW Alerts

European Journal of

Mineralogy

JOURNAL HOME HELP FEEDBACK/COMMNET SUBSCRIBE ARCHIVE SEARCH TABLE OF CONTENTS

European Journal of Mineralogy; November/December; v. 22; no. 6; p. 837-854; DOI: 10.1127/0935-1221/2010/0022-2072

(C) 2010 E. Schweizerbart'sche Verlagsbuchhandlung Science Publishers

This Article

\title{
Other articles
}

\section{Geochemistry of granitic aplite- pegmatite sills and petrogenetic links with granites, Guarda-Belmonte area, central Portugal}

\author{
Ana M.R. Neiva ${ }^{1, *}$ and João M.F. Ramos ${ }^{2}$ \\ ${ }^{1}$ Department of Earth Sciences, and Geosciences Centre, \\ University of Coimbra, 3000-272 Coimbra, Portugal \\ 2 LNEG, National Laboratory of Energy and geology 4466- \\ 956 S. Mamede de Infesta, Portugal \\ * Corresponding author, e-mail: neiva@dct.uc.pt
}

Granitic amblygonite-subtype and lepidolite-subtype, aplite-

Figures Only

Full Text

Full Text (PDF)

Alert me when this article is cited

Alert me if a correction is posted

Citation Map

Services

Email this article to a friend

Similar articles in this journal

Alert me to new issues of the journal

Download to citation manager

(C) Get Permissions

Google Scholar

Articles by Neiva, A. M. R.

Articles by Ramos, J. M. F.

GeoRef

GeoRef Citation

pegmatite sills intruded a biotite $>$ muscovite granite (G1). Two other biotite $>$ muscovite granites (G2 and G3) and a muscovite> biotite granite (G4) crop out in the area. Variation diagrams for major and trace elements of the Variscan rocks show fractionation trends for a) G1 and G4; b) G2, G3 and aplite-pegmatite sills. The two series are confirmed by the two trends defined by major elements of primary muscovite. The sills also contain Li-bearing muscovite, which has higher $\mathrm{Mn}, \mathrm{Li}, \mathrm{F}$ and paragonite contents and lower $\mathrm{Al}^{\mathrm{VI}}$ content than primary muscovite from $\mathrm{G} 2$, G3 and sills. All sills have pure albite and $\mathrm{P}_{2} \mathrm{O}_{5}$ content of $\mathrm{K}$-feldspar and plagioclase increases in the series $\mathrm{G} 2, \mathrm{G} 3$ and sills. Beryl occurs in all sills, but lepidolite and a nearly pure petalite only occur in lepidolitesubtype sills, which are the most evolved sills. Primary topaz and amblygonite have a similar composition in all sills. Aplite-pegmatite sills contain cassiterite, which shows sequences of alternating darker and lighter zones. The former are richer in $(\mathrm{Nb}+\mathrm{Ta}+\mathrm{Fe}+\mathrm{Mn})$ than the latter. Manganocolumbite is common in all sills, but ferrocolumbite only appears in amblygonite-subtype sills and manganotantalite in lepidolite-subtype sills. The sills richest in Li contain reversely-zoned crystals with a homogeneous microlite core and a heterogeneous uranmicrolite rim. Least squares analysis of major elements shows that granite G3 and amblygonite-subtype and lepidolite-subtype aplite-pegmatite sills can be derived from granite G2 magma by fractional crystallization of quartz, 
Geochemistry of granitic aplite-pegmatite sills and petrogenetic links with granites, G... Page 2 of 2

plagioclase, K-feldspar, biotite and ilmenite. Modelling of trace elements shows good results for $\mathrm{Sr}$, but magmatic fluids controlled the $\mathrm{Rb}$ and $\mathrm{Ba}$ contents of the aplite-pegmatite sills and probably also their $\mathrm{Li}, \mathrm{F}, \mathrm{Sn}$ and Ta contents and crystallization of lepidolite, cassiterite and $\mathrm{Nb}-\mathrm{Ta}$ oxide mineral assemblage. Schorl from the lepidolite-subtype sills that cut granite $\mathrm{G} 1$ has higher $\mathrm{Mg} /(\mathrm{Mg}$ $+\mathrm{Fe}$ ) than schorl from metasomatised granite at sill walls and resulted from the mixing of magmatic fluids carrying B and some Fe with a meteoric fluid that has interacted with the host granite G1 and carried $\mathrm{Fe}$ and $\mathrm{Mg}$. Schorl and dravite, respectively from metasomatised granite and micaschist at sill walls, were also formed from the mixing processes.

Key-words: granites, aplite-pegmatite sills, feldspars, micas, Sn- and Li-enrichments. 